\title{
Review
}

\section{Starve and immolate: The politics of human weapons}

\author{
Banu Bargu \\ Columbia University Press, New York, 2014, xvi+480 pp., ISBN: 978-0231163408 \\ Contemporary Political Theory (2017) 16, 158-160. doi:10.1057/cpt.2015.63; \\ advance online publication 15 December 2015
}

\begin{abstract}
Almost exactly 40 years have passed since the publication of Michel Foucault's Discipline and Punish, and its fundamental influence on late modern social theory does not seem to weaken. Banu Bargu's stunningly original and elegantly written Starve and Immolate is also a book about prisons, and it is Foucauldian to the core (and title). But it is much more than an application of a well-known approach or method to a specific subject; it is a major contribution to debates on the current state of sovereignty, biopolitics and statehood. Similarly, the object of her study is a particular episode in recent Turkish political history: namely, the death-fast movement that emerged out of the radical (extra-parliamentary and often illegal) Left protesting against the state's (successful) attempt to introduce high-security prisons, and restructure and securitize the internal organization of prison life between 2000 and 2007. The book is rooted in the thoroughly researched political ethnography from which it starts. However, it also transcends this ethnography since the bold theoretical ambition is to derive a better structural understanding of the politics of life and death and the role of the body in it.

After a long but concise introduction, in a first step Bargu establishes the conceptual framework for her analysis, building on Foucault and Foucaultinspired conceptualizations of sovereignty. Against interpretations that see in biopolitics the overcoming and making obsolete of sovereignty and the power over life and death, she proposes to read the new regime of power as a 'biosovereign assemblage' (p. 53). It entails different, even contradictory modalities of power assigning rather different places and functions to the body, its flourishing and survival. Contemporary power therefore increasingly combines sovereign and biopolitical strategies, a process she calls 'biopoliticazion of sovereignty' (p. 31). Its counterpart, on the side of resistance to power, is the 'necropoliticization of resistance' (p. 31) that she will try to describe in her empirical material. When power becomes preoccupied with life, so does resistance, but this can result in a politicization of life, or, as in her cases, of death.
\end{abstract}

(C) 2016 Macmillan Publishers Ltd. 1470-8914 Contemporary Political Theory Vol. 16, 1, 158-160 www.palgrave.com/journals 
In a second step, the book provides a helpful overview of some main currents of Turkish political history and state ideology, from Kemalism to the coup d'état of 1997 and to the present. This contextualization clarifies the crucial role of prisons as sites of sovereignty and of political struggle, especially after the introduction of antiterror laws since 1991 and the rapid growth of overall prisoner population and of the number of political prisoners, mainly members of illegal parties. This made the prison a symbolic site for the defiance of state sovereignty, and the traditional ward structure even gave room for practices of self-organization and communal life among political prisoners, turning the wards 'into islands of communism' (p. 164). The implementation of high-security (so-called 'F-type') prisons with small or single cell units was intended to eradicate this political counterculture within the prisons.

The fierce resistance against this strategy of 'cellularization' (p. 164), whose political history Bargu narrates in a third step, eventually gave rise to a persistent and highly publicized movement of hunger strikes and then hunger fasts unto death, with the state responding frantically in a combination of authoritarian, violent and permissive strategies, ranging from artificial feeding to a large-scale discharge of death-fasting prisoners. Bargu interprets these strategies as the counter-attack from the side of the biosovereign state that sees its very basis under threat where the subjects or lives to be contained turn their fragile life against itself and against the sovereign capture.

It is the long process of the 'weaponization of life' (p. 165) in the death-fast within and outside the prison in so-called 'resistance houses' that is then narrated in a fourth step, with close attention to the prisoner activists and their political demands, coalition tactics and forms of action. Bargu convincingly shows how different rhetorics govern this struggle, from invocations of a universal right to determine one's own death to more radical conceptions of political martyrdom. In a fifth step, she contextualizes these tropes in the history of Turkish Marxism and party ideologies. The death-fast movement could activate and invent elements of a secular 'political mysticism, a secularized political theology' (p. 237), assigning to the protagonists of the movement the almost sanctified place of the 'militant-martyr' (p. 240). Bargu describes the system of meticulous rituals accompanying the deathfast, its modes of recruitment and preparation, and the discursivity deriving from it in funeral speeches and political statements. This part of the book is the most impressive, and the reader cannot but imagine the difficulties in conducting the (mainly interview) research leading to these descriptions.

In a sixth step, Bargu reconstructs and discusses the many interpretations of the political nature of the death-fast advanced by the protagonists themselves. Sometimes it figured as an act of resistance against the illiberal state or an act of war in the course of class struggle, by some it was seen as a radical act of complete refusal, 'an ideological offensive against biosovereign power whose legitimacy depended on the "sanctity" of human life' (p. 274), a 'fatal exodus' (p. 309). Bargu asserts that all of these interpretations were present and articulated by different protagonists, testifying 
to the 'multifaceted nature of the movement' (p. 309). Long lists of the dead in this struggle in the middle and near the end of the book movingly and uncannily underscore the fact that even this non-partisan historiography of a movement largely unknown outside its principal milieu assumes the role of a work of mourning. Its center is an image of a self-contradictory, paradoxical form of engagement that somehow can be none since it is self-effacing, 'a form of agency that permeates and indeed enables the radical politics by way of its self-destruction' (p. 330).

Bargu leaves no doubt that the political legacy of the movement, despite some concessions made from the side of the state, is uncertain. The theoretical implication of her analysis is straightforward, however. This specific, extreme form of resistance helps us understand that which it resists: 'When human weapons take into their own hands the power of life and death, they challenge the core of sovereign power, latent and subdued through biopoliticization, with which they find themselves in confrontation' (p. 342). Self-afflicted death can be, can become resistance 'insofar as that biopoliticization renders death into a possible site of resistance at the margins of power' (p. 343). Current state politics involves a subtle combination of life-affirming and life-negating elements, and in both registers resistance can be found. This stance can counter the tendency of theoretically reducing all current neoliberal policies to 'productive' interventions and omitting the sheer violence still in play. And it can shed some doubts on the (often Agamben-inspired) tendency of construing a strict, almost absolute dichotomy between political and physical life.

One can easily imagine a book on the same material written in a more cynical mode, exploiting its material for its horrifying effects. Bargu succeeds in steering clear of this temptation; her tone remains calm and full of tact toward the actors in question, and this is no small feat. There is no judgment on their political views or on their overall political strategies (this involving for the most part banned political parties, after all). I would have appreciated some further elaborations on the relationship between these actors and their other political progressive contemporaries. And the account of the secular nature of this political theology of martyrdom in resistance might merit more discussion than is given here. The extremity of the cases of self-destructive political actions Bargu describes refers to an extremity in the nature of contemporary politics itself. The spectacular success of Discipline and Punish was owed partly to the impression it gave that Bentham's panopticon has become an allegory for a society to come. Bargu's stunning book about extreme resistance in Turkish prisons, a prime example of a genre we might call 'drastic political theory', goes as far: These desperate struggles in these marginal places tell us a truth about our contemporary world.

Martin Saar

Leipzig University, Leipzig 04107, Germany martin.saar@uni-leipzig.de 